Кінетичні характеристики сперміїв зааненського козла після їх кріоконсервування

А.О. Богданюк ${ }^{1,2}$, О.О Берестовий ${ }^{1,2}$, В.В. Цвик ${ }^{1}$

${ }^{1} /$ нститут сучасних ветеринарних технологій, с. Черевки, Україна

${ }^{2}$ TOВ «Медичний центр матері», м. Київ, Україна

\title{
Kinetic Characteristics of Spermatozoa of Saanen Goats After Their Cryopreservation
}

A.O. Bogdaniuk ${ }^{1,2}$, O.O. Berestovyy ${ }^{1,2}$, V.V. Tsvik ${ }^{1}$

${ }^{1}$ LLC 'Institute of Contemporary Veterinary Technologies', Cherevky, Ukraine

${ }^{2}$ LLC 'Materi Clinic', Kyiv, Ukraine

Штучна інсемінація кіз є одним із найпоширеніших способів розведення необхідних порід для фермерських господарств. Штучна інсемінація проводиться 3 порівняно невеликою дозою сперми та концентрацією сперматозоїдів у ній [Н. Paulenz, 2007]. Тому один еякулят можна розділити та запліднити ним декілька самок. Якщо достатня кількість готових для запліднення самок відсутня, є можливість зберегти сперму, використовуючи кріотехнології. Для інсемінації кіз молочної породи актуальне використання сперміїв, відібраних за статевою хромосомою, оскільки перевага надається особинам жіночої статі. Після даної обробки сперма позбавляється сім'яної рідини, а кількість сперматозоїдів зменшується, тому важливо зберегти якомога більше живих та рухливих сперміїв для подальшого запліднення.

Мета дослідження - порівняння рухливості кріоконсервованих сперміїв з використанням сім'яної рідини, без сім'яної рідини та після відбору сперміїв за статевою хромосомою.

У дослідженні були використані три статево зрілих самця зааненської породи віком 12-18 місяців. Забір сперми проводили за допомогою штучної вагіни («Міnitub», Німечина) тричі, раз у три дні. Еякулят розділяли на групи: 1 - сперму розводили середовищем «AndroMed $^{\circ} »$ («Minitube», Німеччина) за наведеним в інструкції протоколом до кінцевої концентрації $400 \times 10^{6} /$ мл, 2 - виділена активно рухлива фракція сперміїв у концентрації $400 \times 10^{6}$ /мл, 3 - спермії, які несуть Х хромосому [S. Hadi, 2013]. Усі зразки були заморожені у cередовищі «AndroMed ${ }^{\odot} »$ («Minitube», Німеччина) у кріосоломинах («Minitube», Німеччина) об’ємом 0,250 мл.

Через 72 години кріосоломини розморожували на водяній бані при $37^{\circ} \mathrm{C}$ протягом 30 с та визначали рухливість сперматозоїдів.

Рухливість свіжовиділених сперміїв до кріоконсервування склала $(79,4 \pm 5,3) \%$. Після нагріву зразків групи 1 було виявлено $(53,7 \pm 2,4) \%$ рухливих сперматозоїдів, у групі $2-(41,2 \pm 3,1) \%$, а у групі $3-(37,8 \pm 1,2) \%$. Отримані результати вказують на те, що сім'яна плазма забезпечує збереженість сперміїв, можливо, за рахунок зменшення рівня перекисного окислення ліпідів. Значущої різниці показників рухливості сперміїв груп 2 та 3 не виявлено.

Таким чином, рухливість кріоконсервованих сперміїв самців зааненської породи значущо вища після кріоконсервування з сім'яної рідиною, порівняно 3 виділеними сперміями. Відбір сперміїв за статевою хромосомою не впливає на їх кріорезистентність.
Artificial insemination of goats is one of the most common ways for much-in-demand species breeding in farming. An artificial insemination is performed with a relatively small volume of sperm and spermatozoa concentration in it (H. Paulenz, 2007). Therefore, one sperm dose may be divided for several female goats to be fertilized. If the quantity of female goats in estrus is insufficient, the sperm may be preserved using cryotechnology. As female goat is preferred in dairy breeds, it is relevant to use X-chromosome-bearing sperm selection techniques. After such a processing, the sperms are separated from seminal plasma and the number of spermatozoa decreases, so it is important to preserve as much viable and motile sperm as possible for further fertilization.

The purpose of this study was to compare the motility of cryopreserved spermatozoa with/without seminal plasma use, and after spermatozoa selection by sex chromosome.

Here, we used 3 sexually mature Saanen male goats, aged between 12 and 18 months. The sperm was collected three times every three days using an artificial vagina (Minitub, Germany). The ejaculate was divided into the following groups: the Group 1 comprised the sperm, diluted with AndroMed ${ }^{\odot}$ medium (Minitube, Germany) according to the protocol up to the final concentration of $400 \times 10^{6} / \mathrm{ml}$; the selected fraction of active spermatozoa in $400 \times 10^{6} / \mathrm{ml}$ concentration was the Group 2; the selected $\mathrm{X}$-chromosome-bearing spermatozoa made the Group 3 (S. Hadi, 2013). All the sperm samples were frozen in AndroMed ${ }^{\odot}$ medium (Minitube, Germany) in $0.250 \mathrm{ml}$ straws (Minitube, Germany).

In $72 \mathrm{hrs}$ after sperm cryopreservation, the straws were thawed in a water bath at $37^{\circ} \mathrm{C}$ for 30 seconds and the spermatozoa motility was analyzed.

The motility of fresh spermatozoa before cryopreservation was $(79.4 \pm 5.3) \%$. The spermatozoa motility after thawing in Group 1 was $(53.7 \pm 2.4) \%$, in Group 2 and 3 it made $(41.2 \pm 3.1)$ and $(37.8 \pm 1.2) \%$, respectively. These findings testify to the fact that the seminal plasma provides higher spermatozoa preservation rates, likely due to a decrease in lipid peroxidation level. No significant difference in spermatozoa motility in groups 2 and 3 was revealed.

Thus, the motility of cryopreserved spermatozoa of Saanen goats is significantly higher after cryopreservation with seminal plasma as compared with the selected spermatozoa. The seprmatozoa selection by sex chromosome causes no impact on their cryoresistance. 